\title{
LINSEC - The software for modeling and simulation of grain drying systems $^{1}$
}

\author{
LINSEC - Programa computacional para modelagem e simulação de sistemas de \\ secagem de grãos
}

\author{
Domingos Sárvio Magalhães Valente ${ }^{2 *}$, Daniel Marçal de Queiroz², Luis César da Silva³, Gabriel Henrique Horta \\ de Oliveira ${ }^{4}$ e Fábio Lúcio Santos ${ }^{5}$
}

\begin{abstract}
Considering the importance of mathematical models in the development and analysis of grain drying systems, and understanding the need to develop interfaces that will improve the accessibility of these models, this work aimed to: a) implement the Thompson model to simulate grain drying at high temperatures; b) develop an appropriate language to generate drying models; and c) develop a graphical interface with the goal of facilitating user understanding. Thus the computational program LINSEC that was created using the programming language Visual Basic 6.0. LINSEC was highly effective for the modeling and simulation of drying systems and in providing simulated values close to reality. LINSEC is highly flexible and user-friendly during the modeling of several types of dryers.
\end{abstract}

Key words: Grain dryer. Mathematical models. Thompson's model.

\begin{abstract}
RESUMO - Tendo em vista a importância dos modelos matemáticos no desenvolvimento e análise de sistemas de secagem, além do conhecimento e necessidade de desenvolver interfaces de modo a aprimorar a acessibilidade e uso destes modelos, este trabalho visou: a) implementar o modelo de Thompson de modo a simular a secagem de grãos a altas temperaturas; b) desenvolver uma linguagem apropriada para gerar sistemas de secagem; e c) desenvolver uma interface gráfica com o objetivo de facilitar o entendimento do usuário, utilizando-se a linguagem Visual Basic 6.0. O programa computacional LINSEC, demonstrou uma alta efetividade na simulação de secagem, fornecendo valores próximos à realidade. É flexível e de fácil utilização pelo usuário durante a simulação para diferentes tipos de secadores.
\end{abstract}

Palavras-chave: Secadores de grãos. Modelos matemáticos. Modelo de Thompson.

\footnotetext{
*Autor para correspondência

Recebido publicação em 02/02/2011; aprovado 28/02/2012

The authors would like to acknowledge CNPq and FAPEMIG, agencies of the Brazilian government, for their financial support, essential for the completion of this research

${ }_{2}^{2}$ Departamento de Engenharia Agrícola/UFV, Campus UFV, Viçosa-MG, Brasil, 36.570-000, valente@ufv.br, queiroz@ufv.br ${ }^{3}$ Departamento de Engenharia Rural/UFES, Campus de Alegre, Alegre-ES, Brasil, 29.500-000, silvalc@cca.ufes.br

${ }^{4}$ Instituto Federal de Brasília/Campus Gama, Praça 2, s/n, Setor Central, Brasília-DF, Brasil, 72.405-980, gabriel.oliveira@ifb.edu.br

${ }^{5}$ Departamento de Engenharia Agrícola/UFV, Campus UFV, Viçosa-MG, Brasil, 36.570-000, fabio.ls@ufv.br
} 


\section{INTRODUCTION}

Artificial drying of agricultural products is a technology which usually utilizes high cost equipment with high energy consumption in order to heat the air used for drying (REINATO et al., 2002; SHARMA; CHEN; LAN, 2009). Among drying modalities, drying at high temperatures is the most commonly used technology in commercial grain storage facilities (LUANGMALAWAT et al., 2007). This technology generates a gradient of humidity which accelerates the drying process, extends the shelf life of agricultural products (ERENTURK; ERENTURK; TABIL, 2004) and prevents losses due to the low water activity achieved (ULLMANN et al., 2010). However, it also creates conditions that can cause discoloration, cracks and fissures on the grains (BUNYAWANICHAKUL et al., 2007; LUANGMALAWAT et al., 2007; NISHIYAMA; ZAO; LI., 2005; RAO; BAL; GOSWAMI, 2006). In this case, the equipment must be designed in order to prevent these changes, preserve product quality and maximize dryer efficiency.

The main goal of drying is to remove excess water from the product until it reaches the ideal level of moisture content. This level is required in order to store, process and commercialize grain in a safe mode (JAYAS; WHITE, 2003; LIU et al., 2007; OLIVEIRA et al., 2010). To achieve this objective on a commercial scale, the use of high-capacity dryers that employ high drying-air temperature is recommended. These dryer systems generally imply high acquisition cost, heating energy consumption, and electrical energy usage (REINATO et al., 2002; SHARMA; CHEN; LAN, 2009).

Generally, drying mathematical models are used to predict final moisture content and output product temperature of products and drying time (DALPASQUALE et al., 2007). The mathematical model consists of heat and mass transfer interaction between the product and drying air. Even though empirical equations provide very accurate results for each specific experiment, they are not valid for other conditions. Simulation models are therefore recommended for describing the drying process (MOVAGHARNEJAD; NIKZAD, 2007).

Thompson's model is one of the most rewarding options for simulating grain drying at high temperatures, because of its lower requirement for computational resources and accuracy in estimating the output variables. This model is based on energy and mass transfer laws and an empirical equation of thin-layer drying of grain (DALPASQUALE; SPERANDIO, 2010). It was formulated considering the thin layer concept, with a simultaneous change of moisture content, air and grain temperature, and relative humidity (SOUZA; QUEIROZ; LACERDA FILHO, 2002).
It has been proved that mathematical modeling and simulation are important tools in the development, design and analysis of grain drying systems. These activities normally require programming language skills. Therefore, this scenario indicates the need to develop graphical interfaces that can aid modeling and simulation of drying systems. Therefore, this work presents a computational toolset that provides modeling and simulation drying systems with a graphical interface.

\section{MATERIAL AND METHODS}

A computational program known as LINSEC was implemented through the use of the program Visual Basic, version 6.0. It is a graphically oriented simulation toolset that allows the assemblage of computational models of grain dryers and simulation of the drying process according to Thompson's model. The organized block structure of the model permits the modeling and simulation of several types of grain drying systems.

The blocks are related to air, products and dryers. Each block represents an integral specific part of the drying system. LINSEC disposes of fifteen blocks. In order to model a dryer system, users need to select blocks according to dryer configuration.

LINSEC works in the following way: (a) the blocks that represent the drying system parts are inserted in the workspace; (b) the blocks are connected accordingly to the logic that governs the drying systems, leading to the flow sheet of air and product movement; (c) an instructional code of LINSEC language is generated; and (d) LINSEC compiles the language and simulates the drying on the basis proposed by Thompson, Peart e Foster (1968). The conceptual model related to the modeling of drying systems using LINSEC can be seen in Figure 1.

The drying process was divided into several subprocesses. The grain bed was considered as several layers with reduced thickness, placed upon each other. The variations in the conditions of air and grain in each layer were calculated based on small increments of time. All steps and equations are presented by Souza, Queiroz and Lacerda Filho (2002) and Dalpasquale and Sperandio (2010).

Tables 1, 2 and 3 contain, respectively, information about blocks related to drying air, product properties and dryer configuration. 
Figure 1 - Conceptual model related to the modeling of drying systems using LINSEC

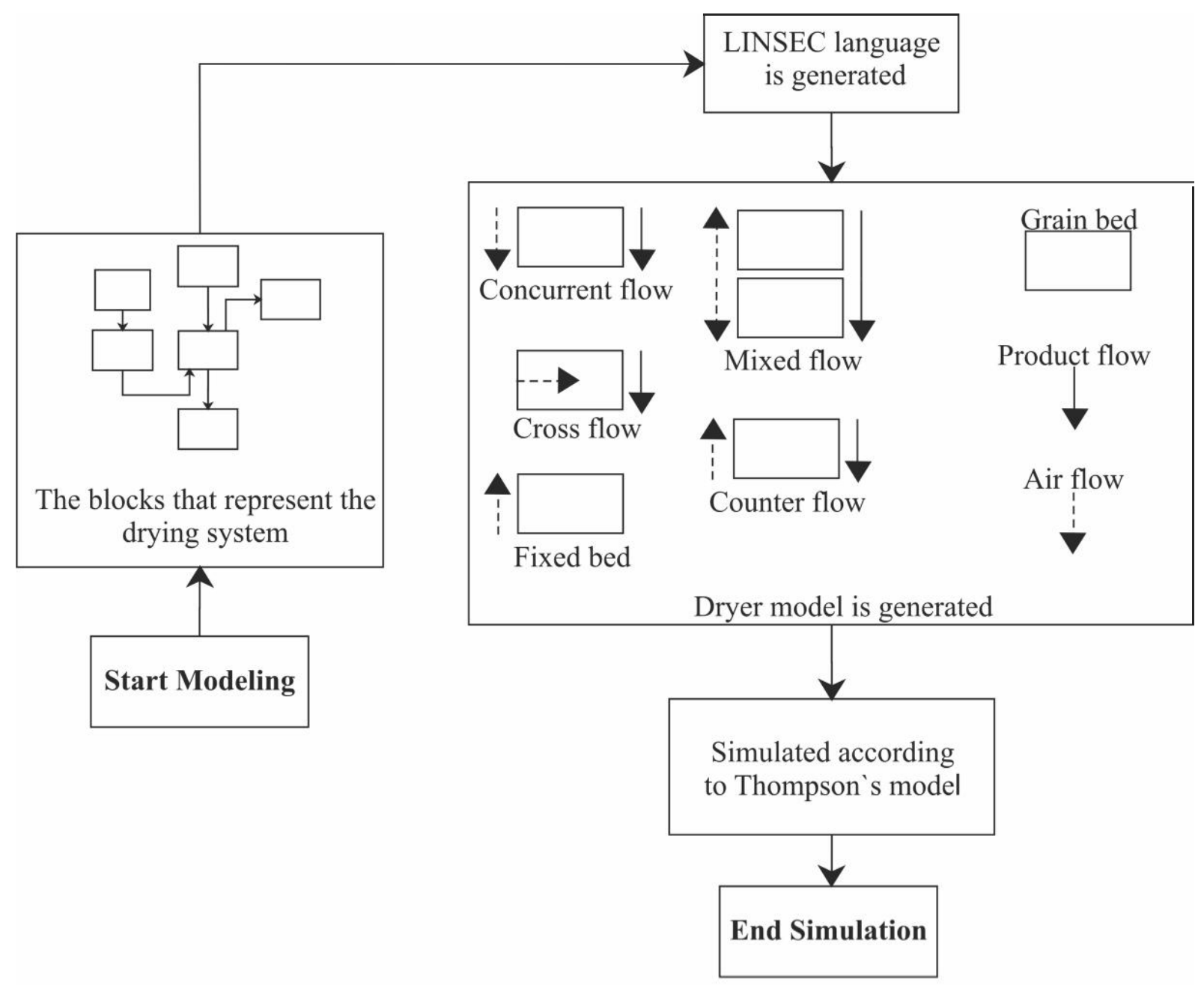

Table 1 - Blocks related to drying air

\begin{tabular}{cl}
\hline Block Name & Description \\
Air source & $\begin{array}{l}\text { Used for defining inlet air conditions such as: } \\
\text { air temperature }\left({ }^{\circ} \mathrm{C}\right) \text {, relative humidity }(\%) \text { and } \\
\text { volumetric flow rate }\left(\mathrm{m}^{3} \mathrm{~s}^{-1}\right) \\
\text { Characterizes heater system according to the } \\
\text { following information: air outlet temperature }\left({ }^{\circ} \mathrm{C}\right), \\
\text { heater system efficiency }(\%) \text {, and energy consumption } \\
\left(\mathrm{kJ} \mathrm{s}^{-1}\right)\end{array}$ \\
Air divider & $\begin{array}{l}\text { Divides airflow in two outlets. User needs to inform } \\
\text { percentage of air flow for which outlets }\end{array}$ \\
Air mixer & $\begin{array}{l}\text { Used for modeling mixing of two airstreams } \\
\text { Mimulation it reports: average air temperature }\left({ }^{\circ} \mathrm{C}\right),\end{array}$ \\
\hline
\end{tabular}


Table 2 - Blocks related to product properties

Block Name
Product inlet

Table 3 - Blocks related to dryer configuration

Slock Name
and hescription
Both cases need to define the airflow direction
section


In order to test LINSEC, two different sets of data related to the corn drying were employed: (i) the first one refers to a fixed bed dryer designed by Silva (1980), and (ii) the second to a concurrent flow dryer developed by Queiroz et al. (1988).

\section{Fixed bed dryer modeling}

Figure 2 shows a flowchart that represents the fixed bed dryer under the same experimental conditions carried out by Silva (1980).
The drying chamber of a fixed bed dryer was modeled with a cross section of $1.0 \mathrm{~m}^{2}$, and column height of $0.305 \mathrm{~m}$ grain. The experimental data of nine drying tests accomplished by Silva (1980) is presented in Table 4.

\section{Concurrent flow dryer modeling}

The Figure 3 presents the flowchart that represents the concurrent flow dryer under the same experimental conditions conducted by Queiroz et al. (1988).

Figure 2 - (a) Conceptual model that represents the fixed bed dryer and (b) model that represents the fixed bed dryer in the LINSEC under the same experimental conditions specified by Silva (1980)
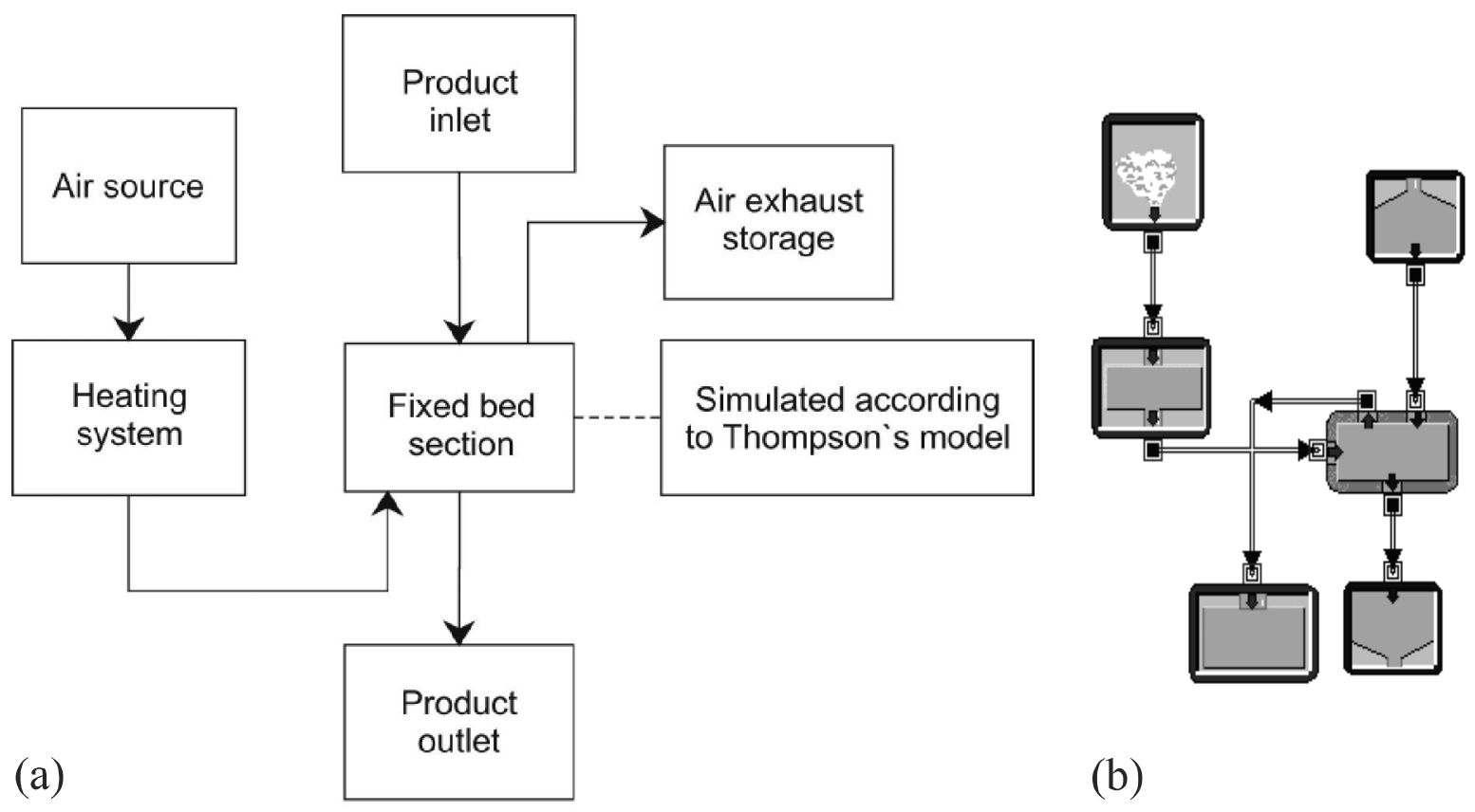

(b)

Table 4 - Drying conditions used in the experimental tests conducted by Silva (1980) and implemented in LINSEC in order to run simulations in the fixed bed dryer for corn

\begin{tabular}{|c|c|c|c|c|c|c|c|c|c|}
\hline \multirow{2}{*}{ Drying conditions } & \multicolumn{9}{|c|}{ Test } \\
\hline & 1 & 2 & 3 & 4 & 5 & 6 & 7 & 8 & 9 \\
\hline $\operatorname{MCi}(\% \text { w.b. })^{1}$ & 28.57 & 28.57 & 27.90 & 26.90 & 24.70 & 24.01 & 24.81 & 25.98 & 35.69 \\
\hline Tpi $\left({ }^{\circ} \mathrm{C}\right)^{2}$ & 18.75 & 17.95 & 7.95 & 8.15 & 12.55 & 11.65 & 10.95 & 9.95 & 12.25 \\
\hline $\operatorname{Td}\left({ }^{\circ} \mathrm{C}\right)^{3}$ & 90.95 & 94.45 & 99.45 & 86.65 & 98.15 & 103.85 & 99.95 & 100.55 & 99.45 \\
\hline $\mathrm{Te}\left({ }^{\circ} \mathrm{C}\right)^{4}$ & 21.25 & 10.65 & 2.85 & 4.85 & 12.65 & 11.15 & 10.15 & 6.85 & 12.55 \\
\hline $\mathrm{RH}(\%)^{5}$ & 55 & 68 & 81 & 58 & 60 & 71 & 2 & 50 & 60 \\
\hline$t(s)^{6}$ & 1764 & 1548 & 1296 & 1044 & 612 & 1116 & 288 & 3600 & 5688 \\
\hline $\mathrm{G}\left(\mathrm{m}^{3} \mathrm{~s}^{-1}\right)^{7}$ & 0.5332 & 0.5332 & 0.5332 & 0.5332 & 0.5332 & 0.5332 & 0.5332 & 0.5332 & 0.5332 \\
\hline
\end{tabular}

${ }^{1 /} \mathrm{MCi}$, initial moisture content of the product; ${ }^{2 / T} \mathrm{Tpi}$, initial temperature of the product; ${ }^{3 /} \mathrm{Td}$, drying air temperature; ${ }^{4 /} \mathrm{Te}$, environment air temperature; ${ }^{5 /} \mathrm{RH}$, relative humidity; ${ }^{6 /} \mathrm{t}$, drying time; ${ }^{7 /} \mathrm{G}$, airflow 
Figure 3 - (a) Conceptual model that represents the concurrent flow dryer and (b) model that represents the concurrent flow dryer in the LINSEC under the same experimental conditions conducted by Queiroz et al. (1988)
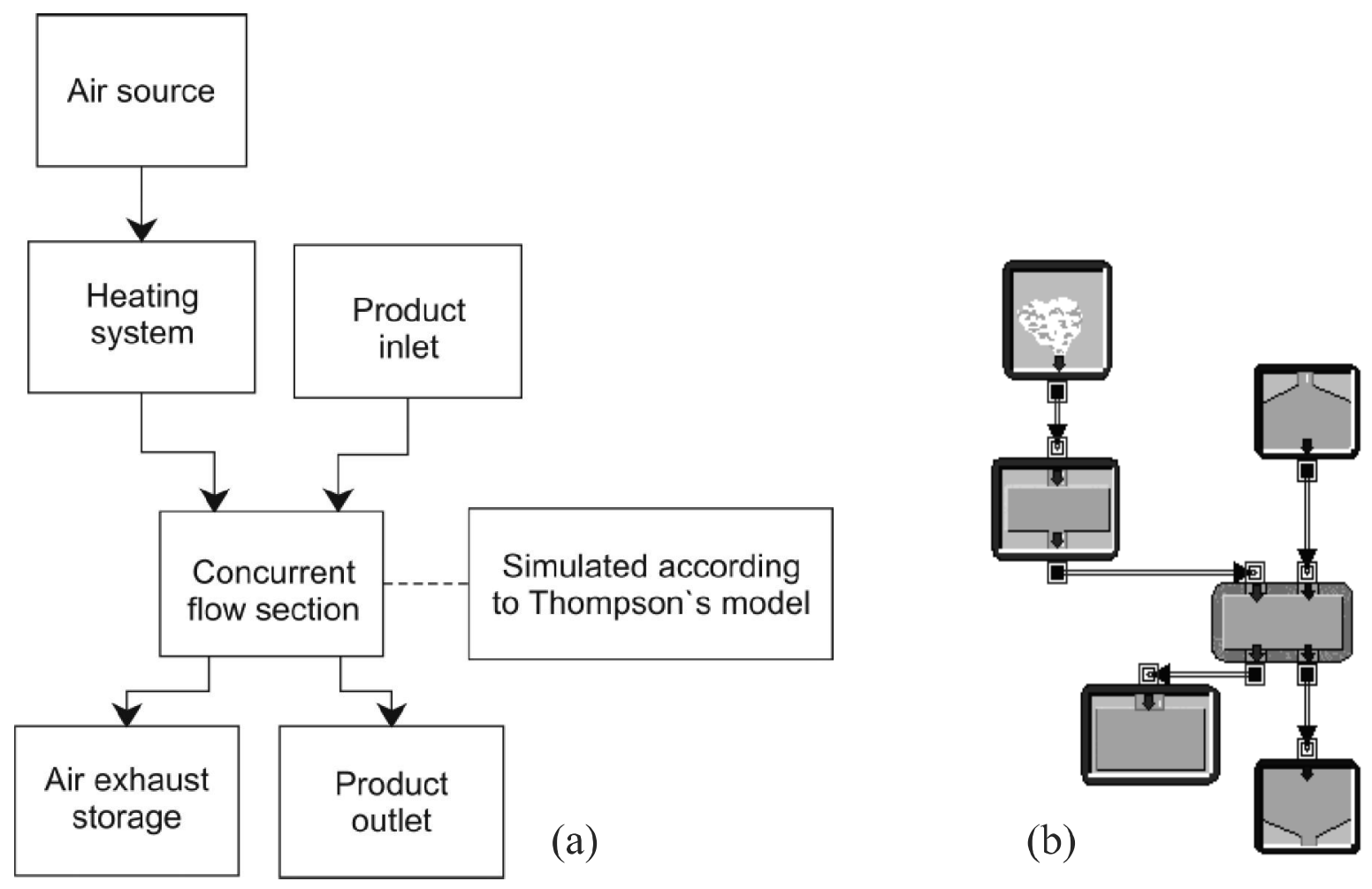

The dryer dimensions are: chamber cross The experimental data of the nine tests conducted by section of $0.25 \mathrm{~m}^{2}$ and grain bed height of $0.60 \mathrm{~m}$. Queiroz et al. (1988) are presented in Table 5.

Table 5 - Experimental conditions of the drying tests performed by Queiroz et al. (1988) and implemented in LINSEC for simulating the corn drying process in the concurrent flow dryer

\begin{tabular}{lccccccccc}
\hline \multirow{2}{*}{ Drying conditions } & \multicolumn{7}{c}{ Test } \\
\cline { 2 - 10 } & 1 & 2 & 3 & 4 & 5 & 6 & 7 & 8 & 9 \\
\hline $\mathrm{MCi}(\% \text { w.b. })^{1}$ & 15.87 & 14.92 & 16.78 & 17.10 & 17.52 & 17.46 & 19.12 & 18.93 & 17.59 \\
$\mathrm{Tpi}\left({ }^{\circ} \mathrm{C}\right)^{2}$ & 26.00 & 29.40 & 29.00 & 29.60 & 27.50 & 30.00 & 28.50 & 28.90 & 27.70 \\
$\mathrm{Td}\left({ }^{\circ} \mathrm{C}\right)^{3}$ & 130.30 & 130.50 & 169.60 & 160.40 & 150.50 & 170.20 & 140.20 & 140.50 & 157.20 \\
$\mathrm{Te}\left({ }^{\circ} \mathrm{C}\right)^{4}$ & 20.90 & 27.40 & 25.10 & 28.50 & 20.00 & 26.70 & 27.20 & 21.80 & 27.60 \\
$\mathrm{RH}(\%)^{5}$ & 72 & 58 & 59 & 59 & 79 & 63 & 58 & 72 & 59 \\
$\mathrm{t}(\mathrm{s})^{6}$ & 12600 & 14400 & 11700 & 10800 & 11700 & 11700 & 10800 & 13500 & 11700 \\
$\mathrm{G}\left(\mathrm{m}^{3} \mathrm{~s}^{-1}\right)^{7}$ & 0.5332 & 0.5332 & 0.5332 & 0.5332 & 0.5332 & 0.5332 & 0.5332 & 0.5332 & 0.5332 \\
$\mathrm{Lr}\left(\mathrm{kg} \mathrm{s}^{-1}\right)^{8}$ & 0.0943 & 0.0658 & 0.0948 & 0.1315 & 0.0930 & 0.0975 & 0.0968 & 0.0695 & 0.1325 \\
\hline
\end{tabular}

${ }^{1 /} \mathrm{MCi}$, initial moisture content of the product; ${ }^{2} / \mathrm{Tpi}$, initial temperature of the product; ${ }^{3 / \mathrm{Td}}$, drying air temperature; ${ }^{4 / \mathrm{Te}}$, environment air temperature; $5 / \mathrm{RH}$, relative humidity; $6 / \mathrm{t}$, drying time; ${ }^{7} / \mathrm{G}$, airflow; ${ }^{8} / \mathrm{Lr}$, loading rate 


\section{RESULTS AND DISCUSSION}

Figure 4 shows the results of the average final moisture content simulated by LINSEC and experimental data obtained by Silva (1980).

Figure 4 - (a) Simulated values of final moisture content versus experimental data obtained by Silva (1980), (b) comparison of simulated and experimental final moisture content in each test and (c) tendency of residual distribution values
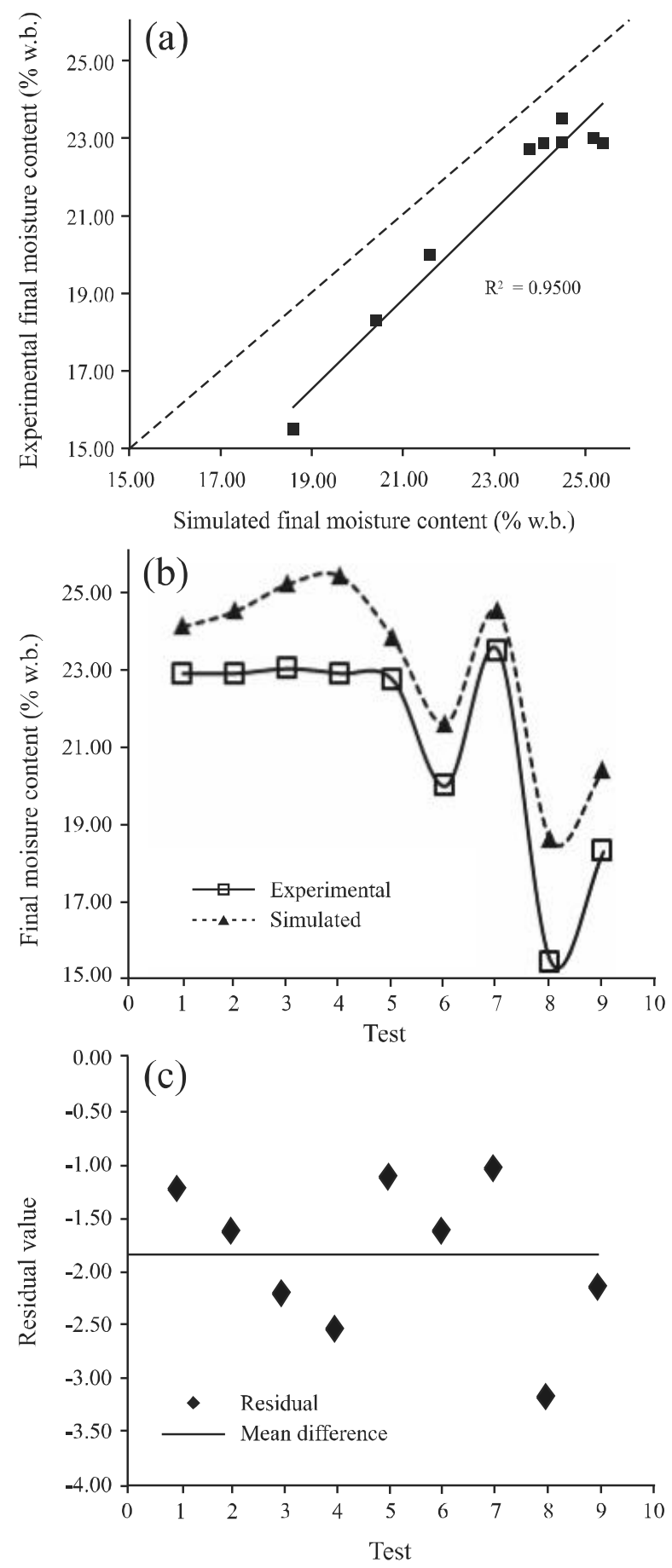

As can be seen in Figure 4, the final moisture content simulated by LINSEC was higher than the experimental data. The mean and maximum absolute differences between simulated and experimental moisture contents were $1.82 \%$ w.b. and $3.13 \%$ w.b., respectively. Martins et al. (1982) performed the same comparative test using the MSU (Michigan State University) simulated and experimental data and obtained the mean and maximum differences of $0.88 \%$ w.b. and $3.45 \%$ w.b., respectively. As showed in Figure 4, the residual values demonstrate that simulated data presented a stochastic distribution and a systematic mean error.

Figure 5 presents the results of the water removed from the grains in the simulated tests versus experimental tests carried out by Silva (1980).

Figure 5 shows that simulated values of the amount of water removed from the grains were underestimated in relation to the experimental values. The mean and maximum absolute differences between the simulated and experimental data were $2.16 \%$ and $3.37 \%$, respectively. As showed in Figure 5, the residual distribution values demonstrate that simulation results presented stochastically distributed and systematic mean error. The correlation coefficient was 0.9840 .

The results of the average final moisture content simulated by LINSEC and experimentally obtained data by Queiroz et al. (1988) can be seen in Figure 6.

According to Figure 6 final moisture content simulated by LINSEC was higher than results obtained by Queiroz et al. (1988). The mean and maximum absolute differences between simulated and experimental final moisture content were $1.05 \%$ w.b. and $1.63 \%$ w.b., respectively. Queiroz et al. (1988), in the same comparison, using the MSU model, obtained the mean and maximum differences of $0.35 \%$ w.b. and $0.70 \%$ w.b., respectively. The largest error observed in this study probably could have been caused by lower accuracy in the Thompsons's model for drying temperatures above $100{ }^{\circ} \mathrm{C}$, as shown in Table 5. In this case, the Michigan model has better accuracy.

Figure 7 shows the results of water removed from the grains in the simulated tests versus the experimental tests obtained by Queiroz et al. (1988).

According to Figure 7 one can conclude that the amount of water removed from the grains in the simulation was underestimated in relation to the experimental values. The mean and maximum absolute differences between the simulated and experimental water removed from the grains were 1.18 and $1.78 \%$, respectively. Complementing the Figure 7 information, one can conclude that residual distribution values of simulated results present trend 
Figure 5 - (a) Water removed from the grains simulated test versus experimental values obtained by Silva (1980), (b) comparison of simulated and experimental water removed from grains in each test, and (c) tendency of residual distribution values
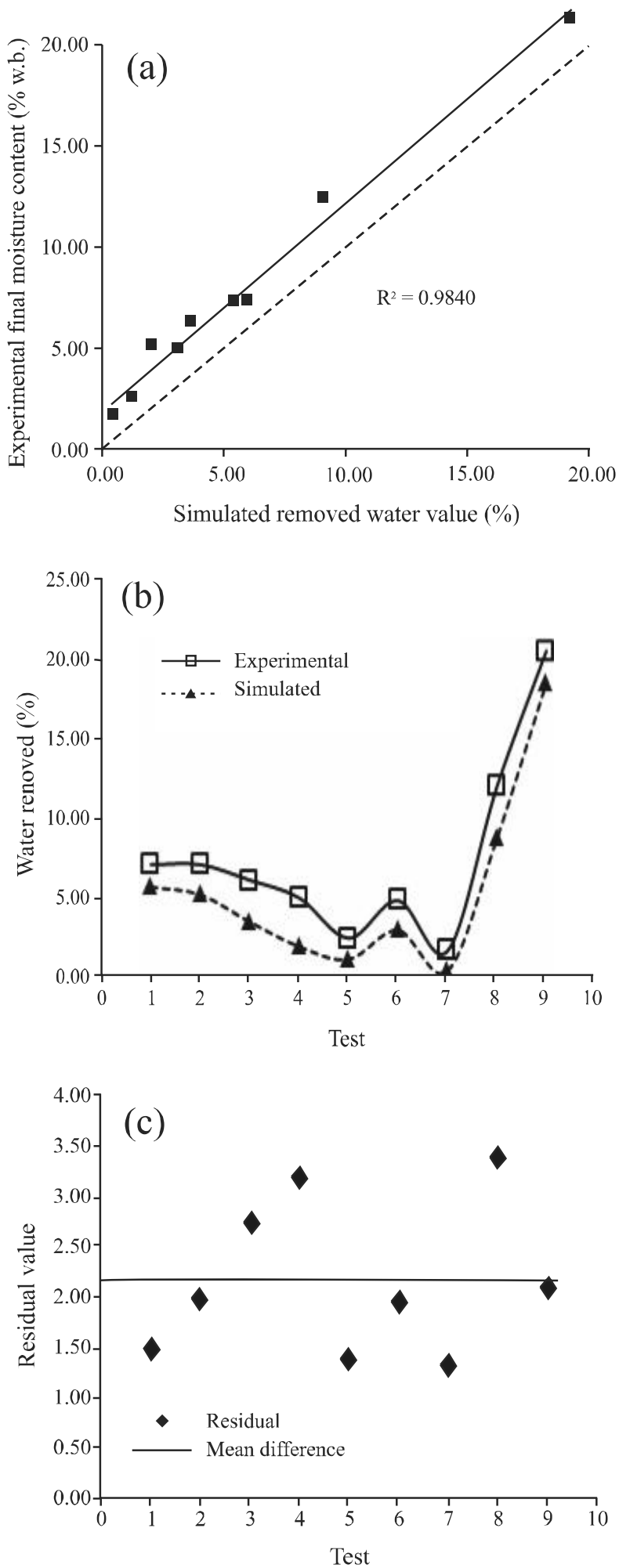

Figure 6 - (a) Simulated final moisture content versus experimental final moisture content obtained by Queiroz et al. (1988), (b) comparison of simulated and experimental final moisture content in each test and (c) tendency of residual distribution values
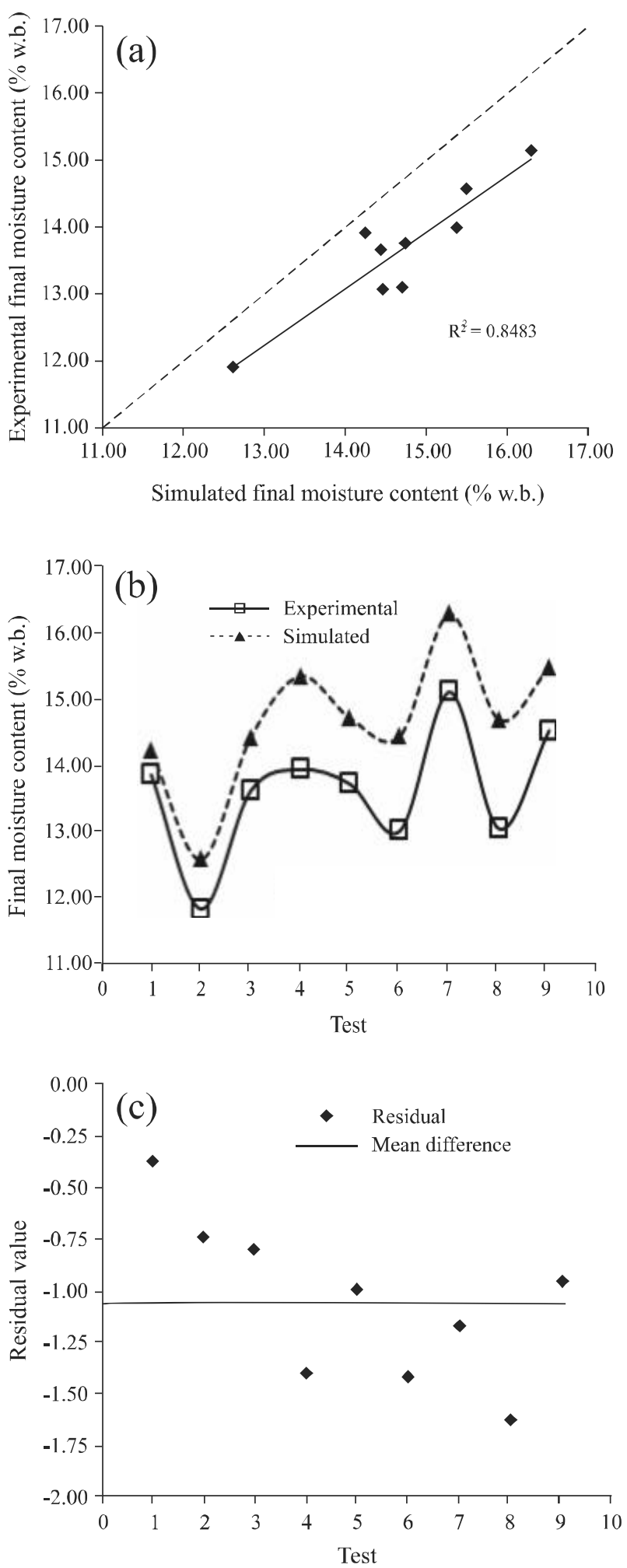
Figure 7 - (a) Water content removed from the grains by simulation versus experimental values of water removed obtained by Queiroz et al. (1988), (b) comparison of simulated and experimental water removed from the grains in each test and (c) Tendency of the residual distribution values
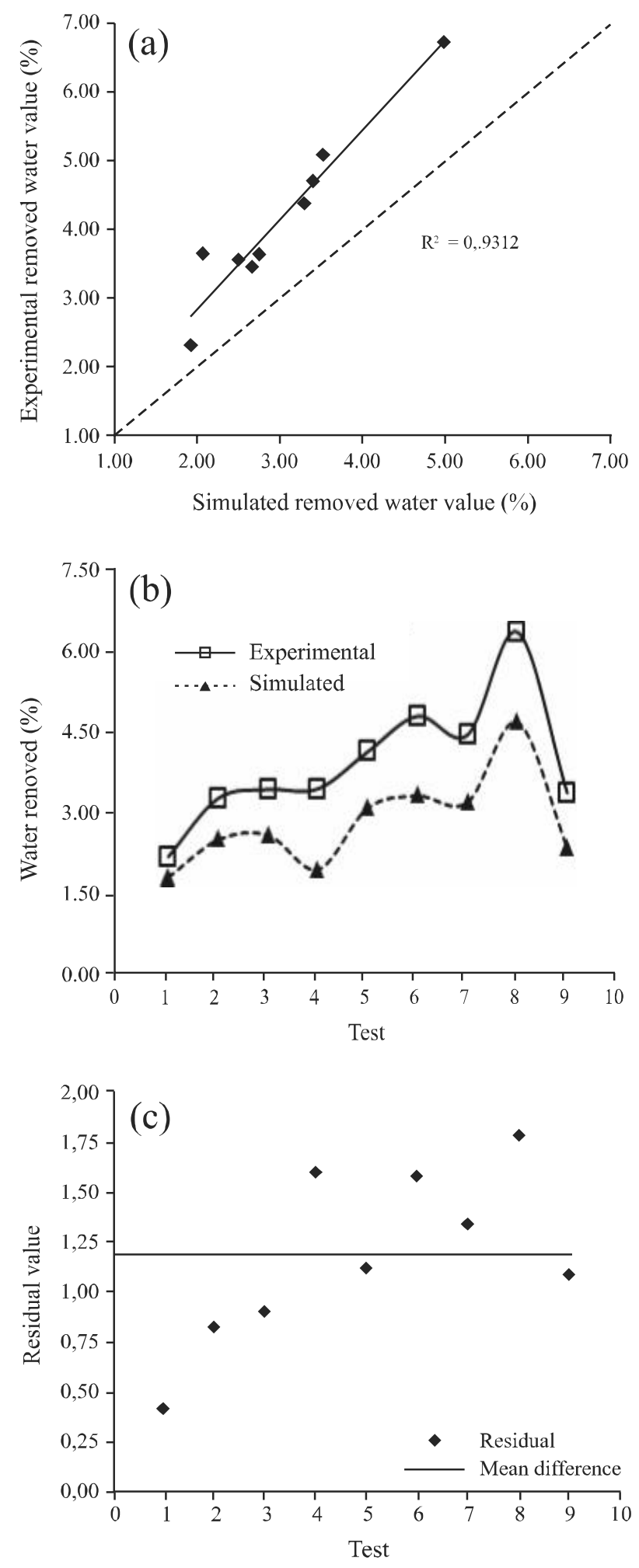

distribution and systematic mean error, and there is increasing tendency of error according to increasing amounts of water removed from grains.

\section{CONCLUSIONS}

1.According to the test procedures, LINSEC, a toolset for modeling grain dryers, can be used for modeling and simulating a concurrent flow drier and fixed bed dryer, with the great advantage of not demanding user knowledge of programming languages;

2.Modeling drying systems using LINSEC is an easy procedure that offers a large number of users the opportunity to use simulation at the development, design, evaluation and analysis of drying systems.

\section{ACKNOWLEDGEMENTS}

The authors thank CNPq and FAPEMIG for the indispensable funding source and support.

\section{REFERENCES}

BUNYAWANICHAKUL, P. et al. Modeling and Simulation of Paddy Grain (Rice) Drying in a Simple Pneumatic Dryer. Biosystems Engineering, v. 96, n. 03, p. 335-344, 2007.

DALPASQUALE, V. A. et al. Fixed-bed drying simulation of agricultural products using a new backward finite difference scheme. Applied Mathematics and Computation, v. 200, n. 02, p. 590-595, 2007.

DALPASQUALE, V. A.; SPERANDIO, D. Modelo de simulação de secagem de produtos agrícolas usando entalpia do ar constante. Engenharia Agrícola, v. 30, n. 04, p. 726-731, 2010.

ERENTURK, K.; ERENTURK, S.; TABIL, L. G. A comparative study for the estimation of dynamical drying behavior of Echinacea angustifolia: regression analysis and neural network. Computers and Electronics in Agriculture, v. 45 , n. 01/03, p. 71-90, 2004.

JAYAS, D. S; WHITE, N. D. G. Storage and drying of grain in Canada: low cost approaches. Food Control, v. 14, n. 04, p. 255-261, 2003.

LIU, X. et al. A neural network for predicting moisture content of grain drying process using genetic algorithm. Food Control, v. 18, n. 08 , p. $928-933,2007$.

LUANGMALAWAT, $\mathrm{P}$ et al. Effect of temperature on drying characteristics and quality of cooked rice. LWT - Food Science and Technology, v. 41, n. 04, p. 716-723, 2007.

MARTINS, J. H. et al. Simulação de secagem de milho em camada estacionária. Revista Brasileira de Armazenamento, v. 07, n. 01, p. 05-18, 1982. 
MOVAGHARNEJAD, K.; NIKZAD, M. Modeling of tomato drying using artificial neural network. Computers and Electronics in Agriculture, v. 59, n. 01/02, p. 78-85, 2007.

NISHIYAMA, Y.; CAO, W.; LI, B. Grain intermittent drying characteristics analyzed by a simplified model. Journal of Food Engineering, v. 76, n. 03, p. 272-279, 2005.

OLIVEIRA, G. H. H. et al. Desorption isotherms and thermodynamic properties of sweet corn cultivars (Zea mays L.). International Journal of Food Science and Technology, v. 45, n. 03, p. 546-554, 2010.

QUEIROZ, D. M. et al. Simulação de secagem de milho em secadores de fluxos concorrentes de um estágio. Revista Brasileira de Armazenamento, v. 13, n. 01, p. 07-10, 1988.

RAO, P. S.; BAL, S.; GOSWAMI, T. K. Modelling and optimization of drying variables in thin layer drying of parboiled paddy. Journal of Food Engineering, v. 78, n. 02, p. 480-487, 2006.
REINATO, C. H. R. et al. Consumo de energia e custo de secagem de café cereja em propriedades agrícolas do sul de Minas Gerais. Revista Brasileira de Engenharia Agrícola e Ambiental, v. 06, n. 01, p. 112-116, 2002.

SHARMA, A.; CHEN, C. R.; LAN, N. V. Solar-energy drying systems: A review. Renewable and Sustainable Energy Reviews, v. 13, n. 06/07, p. 1185-1210, 2009.

SILVA, J. S. An engineering-economic comparison of five drying techniques for shelled corn on Michigan Farms. EUA: Michigan State University, 1980. $200 \mathrm{f}$.

SOUZA, C. M. A.; QUEIROZ, D. M.; LACERDA FILHO, A. F. Simulação do Processo de Secagem de Sementes de Milho em Camada Fixa. Scientia Agricola, v. 59, n. 04, p. 653-660, 2002.

THOMPSON, T.L.;PEART, R.M.;FOSTER, G.H. Mathematical simulation of corn drying: a new model. Transaction of the ASAE, v. 11, n. 04, p. 582-586, 1968.

ULLMANN; R. et al. Seed quality of jatropha under different drying air conditions. Revista Ciência Agronômica, v. 41, n. 03, p. 442-447, 2010 